\title{
Perkembangan Industri Litik Penghuni Gua-Gua Di Jawa Timur
}

\section{Indah Asikin Nurani}

Keywords: stone tools, lithic, technology, flaking, flintknapping, typology, raw material

\section{How to Cite:}

Nurani, I. A. (2004). Perkembangan Industri Litik Penghuni Gua-Gua Di Jawa Timur. Berkala Arkeologi, 24(1), 1-13. https:/ / doi.org/10.30883/jba.v24i1.889

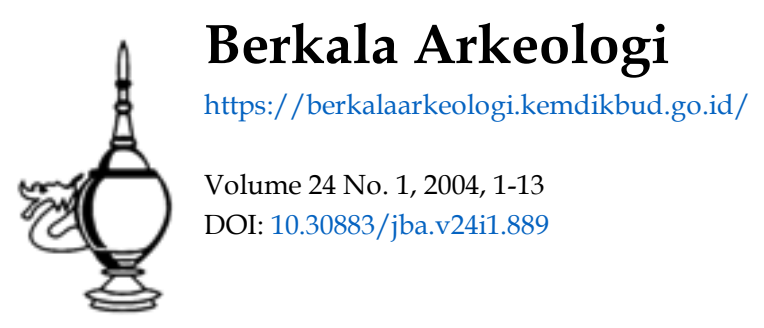

\section{(c) (i) (9)}

This work is licensed under a Creative Commons Attribution-NonCommercial-ShareAlike $\underline{4.0 \text { International License. }}$ 


\title{
PERKEMBANGAN INDUSTRI LITIK PENGHUNI GUA-GUA DI JAWA TIMUR
}

\author{
Indah Asikin Nurani
}

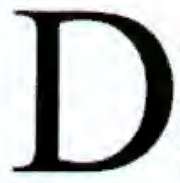

alam teknologi alat-alat batu prasejarah, Indonesia memiliki proses perkembangan yang identik dengan perkembangan teknologi alat batu secara umum, dari bentuk sederhana menuju bentuk yang lebih kompleks dan sempurna. Proses perkembangan tersebut dalam dimensi waktu merupakan suatu proses evolusi teknologis yang cukup panjang yang dikenal dengan istilah paleolitik (batu tua), mesolitik (batu madya), dan neolitik (batu muda). Peristilahan tersebut merupakan terminologi teknologis (Soejono, 1981). Di lain pihak, perkembangan teknologis tersebut menunjukkan tingkat perkembangan yang mengkhaskan suatu budaya. Teknologi paleolitik berkembang pada pola hidup manusia yang masih mengembara (nomaden), teknologi mesolitik berkembang pada kehidupan hunian di gua-gua atau ceruk, sedangkan neolitik berkembang pesat pada pola hidup pertanian (bercocoktanam).

Dalam teknologi alat batu terdapat dua faktor yang melandasi, yaitu metode dan teknik. Metode berada pada bentuk fikiran, sedangkan teknik berada di kedua belah tangan. Metode pembuatan alat merupakan suatu tatanan yang dijalankan secara sistematis dan teratur dan bukan merupakan sesuatu yang terjadi secara kebetulan. Demikian pula halnya dengan ciri-ciri teknologis seperti dataran pukul (strikingplatform), bulbus (bulb of percussion), tatu penyerpihan (bulbar scar), dan alur penyerpihan (ripples) merupakan akibat dari teknologi pernbuatan yang diterapkan oleh si pembuat (Crabtree dalam Widianto, 1984). Cara pembuatan alat-alat batu dengan teknik yang sama dan berlangsung selama ratusan tahun tersebut telah menghasilkan bentuk dan ciri-ciri teknologis yang sama di berbagai tempat di dunia.

\section{A. Perkembangan Industri Litik}

lat-alat batu atau yang disebut industri litik dibagi dalam dua alat yaitu alat
masif dan non masif atau serpih bilah. Perbedaan kedua alat tersebut terletak
pada aspek teknologis yaitu alat masif merupakan alat dari bongkahan batu kemudian dibuat pangkasan-pangkasan yang menghasilkan alat, sedangkan alat non masif merupakan alat dengan teknik pelepasan dari batu inti, sehingga dalam satu bongkah batu dapat menghasilkan beberapa alat non masif. Mengingat perkembangan teknologi litik yang berlangsung pada masa hunian gua atau ceruk adalah serpih bilah, untuk itu dalam tulisan ini hanya dibahas pada jenis alat tersebut. Ciri teknologis serpih bilah adalah eksistensi bulbus-bulbus negatif pada bagian dorsal, bagian ventral tanpa faset, dan adanya dataran pukul. Ciri seperti ini sering kali bertambah ragamnya 
yang diakibatkan oleh ketahanan jenis dan sifat batuan terhadap pukulan yang keras oleh manusia saat alat serpih dilepaskan dari batu inti, seperti adanya kerucut pukul (bulbus), tatu penyerpihan (bulbar-scar), alur penyerpihan (ripples), dan retak-retak penyerpihan (fissures). Ciri-ciri terakhir tersebut akan ada pada alat serpih yang dibuat dari bahan dasar berkualitas tinggi, seperti proses silikaan lanjut dengan butiran halus.

Selain ciri-ciri teknologis tersebut, pelepasan alat-alat serpih bilah dari batu inti dapat dilakukan dengan pukulan langsung (direct-percussion) dan tidak langsung (indirectpercussion). Faset-faset (bulbus negatif) pada bagian dorsal dibentuk terlebih dahulu, kemudian diikuti dengan pembuatan dataran pukul, dan dengan menggunakan perkutor dipukul dengan keras untuk melepaskan alat-alat serpih ini dari batu inti. Umumnya bagian ventral dibiarkan polos, tanpa dilakukan penghalusan melalui pemangkasan kedua (secondary retouched), namun ada juga yang dilakukan pemangkasan kedua terutama pada jenis alat lancipan dan mata panah yaitu untuk membentuk tajaman.

Perkembangan teknologis serpih bilah dari batu tua sampai dengan batu muda masingmasing memiliki kekhasan sendiri-sendiri yaitu sebagai berikut:

\section{Paleolitik}

Alat-alat serpih bilah pada teknologi paleolitik merupakan serpih bilah dengan teknik paling sederhana yaitu masih menonjolkan pembuatan alat melalui teknik pemangkasan (chipping) dan penyerpihan (flaking). Teknik pemangkasan dilakukan pada satu muka (monofasial) ataupun dua muka (bifasial). Alat-alat serpih bilah pada tingkat teknologi ini, lebih sering diterapkan teknik penyerpihan saja dengan produk utamanya berupa alat serpih (flake), bilah (blade), dan serut (scraper).

\section{Mesolitik}

Pada tingkat teknologi mesolitik, sebagian produk alat batu tingkatan paleolitik masih dipertahankan dan diteruskan dengan peningkatan yang lebih cermat pada teknik pembuatan dan variasi produknya. Peningkatan lebih lanjut dan cermat lebih ditujukan pada pemangkasan dan menonjolnya penyerpihan kedua (secondary-retouched). Produk teknologi pada tingkatan ini lebih bervariasi yaitu selain variasi yang lebih berkembang dari tipe serpih, bilah, dan serut, muncul tipe lain berupa lancipanlancipan mikrolit dan mata panah sederhana.

\section{Neolitik}

Tingkatan teknologi ini memiliki perkembangan yang lebih lanjut dan cermat dibanding tingkatan mesolitik yaitu melalui pemangkasan yang lebih kompleks. Ciri yang menonjol adalah adanya penghalusan (grinding) dan pengupaman (polishing), produk serpih bilah pada tingkatan ini antara lain adalah lancipan, mata panah, dan gurdi. Pada tingkatan teknologi ini diimbangi dengan pola hidup yang sudah mengenal cocok tanam, sehingga produk yang dihasilkan menunjukkan adanya 
pemanfaatan dalam aktivitas bertani, seperti lancipan, mata panah dengan berbagai jenis seperti berdasar bundar, bergerigi, dan sudah dibentuk suatu perbengkelan yang menyebabkan ditemukannya tatal-tatal batu sebagai limbah pembuatan alat.

Berdasarkan uraian tersebut di atas, tampak jelas adanya perkembangan baik secara teknologis maupun dalam pola hidup manusia masa prasejarah. Berkaitan dengan tulisan ini, maka pembahasan akan dititikberatkan pada perkembangan industri litik pada pola hidup manusia di gua-gua atau ceruk. Permasalahan yang mendasari tulisan ini adalah : bagaimana perkembangan teknologis yang dikembangkan penghuni guagua di Jawa Timur? dan bagaimana pengaruh bahan baku yang tersedia di lingkungan sekitarnya mempengaruhi produk alat litiknya?

\section{B. Potensi industri litik pada gua-gua hunian di Jawa Timur}

Tebagaimana dijelaskan, industri litik yang berkembang pada pola hidup gua atau ceruk merupakan teknologi mesolitik (alat-alat cenderung berukuran kecil atau mikrolith dan mulai dikenalnya penyerpihan sekunder). Adapun gua atau ceruk yang mengindikasikan sebagai hunian di Jawa Timur hampir semuanya ditemukan alat-alat litik, perbedaannya terletak pada ketersediaan bahan baku dalam hal ini batu baik kualitas maupun kuantitas bahan.

Bahan baku alat sangat berpengaruh dalam perkembangan teknologis yang dikenal para artisan sehingga akan mempengaruhi kualitas alat-alat yang dihasilkan. Berikut potensi industri litik yang berhasil ditemukan pada gua atau ceruk hunian di Jawa Timur. Gua-gua yang berada pada kawasan Gunung Sewu dalam hal ini terbagi atas dua bagian yaitu bagian barat dan timur. Bagian barat yaitu di Gua Braholo, Rongkop, Gunungkidul sedangkan bagian timur Song Keplek, Punung, Pacitan. Kedua gua pada kawasan yang sama memiliki kualitas bahan baku batu yang berbeda yaitu pada Gua Braholo lingkungan alam sekitarnya banyak menyediakan batugamping dengan tingkat silkaan (kersikan) rendah sehingga mudah rapuh dan sulit dikendalikan dalam pemangkasannya. Sedangkan Song Keplek memiliki bahan baku batu dengan tingkat silikaan tinggi yaitu dari batu rijang (chert), kalsedon, dan beberapa gampingkersikan (Simanjuntak, 1999).

Temuan industri litik di kawasan Gunung Sewu ini menunjukkan teknologi yang tinggi dengan dikenalnya penyerpihan sekunder yaitu pembentukan retus-retus untuk mempertajam alat. Alat-alat produk Gua Braholo menunjukkan alat dengan ukuran relatif besar seperti serpih besar tanpa retus dan serut. Hal tersebut disebabkan bahan baku alat merupakan batugamping dengan tingkat silikaan rendah yang mudah rapuh, sehingga pembentukan alat tidak mampu mencapai pemangkasan kecil. Berbeda halnya dengan produk alat dari Song Keplek menunjukkan teknologi tinggi dan didukung bahan baku dengan tingkat silikaan tinggi sehingga mampu menghasilkan 
alat serpih berukuran kecil dengan penyerpihan sekunder yang rumit berukuran mikro. Produk alat litik dari Song Keplek meliputi serpih dengan atau tanpa retus, bilah, serut, bor, dan mata panah.

Bahan baku dan produk alat temuan di gua-gua kawasan Gunung Sewu ini berbeda dengan yang terdapat pada kawasan Gunung Watangan khususnya di Gua Macan yang secara administratif terletak di perbatasan kecamatan antara Puger dan Wuluhan, Kabupaten Jember. Ketersediaan bahan baku batu pada kawasan ini adalah batu gamping dengan tingkat silikaan rendah (Nurani, 2002a). Secara umum, bahan dasar alat yang dipakai adalah jenis batugamping kersikan (silicified-limestone). Pengamatan megaskopis terhadap materi dasar ini menunjukkan kualitas batugamping dari Lojejer ini tidaklah sebaik kualitas materi dasar yang dipakai di kawasan Gunung Sewu, karena kondisi silikaan yang belum lanjut. Selain jenis batugamping yang lebih muda tersebut, kualitas bahan juga kurang baik karena ukuran butiran yang lebih kasar dengan serat-serat batu yang lebih dominan. Struktur batuan seperti ini lebih mudah pecah apabila dipangkas. Bahan dasar jenis ini terdapat pada seluruh temuan artefak batu, kecuali pada sebuah kapak perimbas (chopper) atau lebih dikenal sebagai core tool dalam konteks hunian gua, yang dibuat melalui teknik clacton hasil survei permukaan di Ceruk Gelatik yang dibuat dari andesitkersikan (silicified-andesite). Bahan dasar alat-alat batu tersebut diambil dari lokasi setempat yang merupakan lingkungan gua kapur yang terletak pada jajaran Pegunungan Selatan Jawa Timur.

Selanjutnya gua-gua yang terletak di kawasan Sampung, Ponorogo memiliki kualitas bahan baku rijang (chert) yang menyebar luas baik berupa bongkah maupun fragmentaris di lingkungan perbukitan kapur Sampung (Nurani, 2002b). Keberadaan bahan baku seperti rijang (chert) berwarna merah, coklat, kuning, dan hijau kemudian meta gamping (silicified limestone), dan andesit (andesite) dapat dijumpai dalam radius $1 \mathrm{~km}^{2}$, sedang bahan baku silisifikasi tufa (silicified tuff), kalsedon (calsedone) ataupun kwarsa (quarst) kemungkinan dapat ditemui dalam radius lebih dari $1 \mathrm{~km}^{2} \mathrm{ke}$ arah utara. Hal ini dapat diungkapkan karena proses pengendapan dan hidrotermal sangat dominan di wilayah utara dibanding wilayah selatannya. Himpunan batu rijang merah, coklat, dan kuning serta andesit cukup tersebar dan dapat dijumpai pada aliran Kali Areng yang mengalir membelah bukit-bukit yang ada di gugusan Gunung Angel. Keberadaan rijang hijau maupun meta gamping dapat dijumpai pada teras-teras di dataran rendah atau perbukitan yang ada di sekitarnya. Bahan baku tersebut muncul sebagai proses hidrotermal yang mengintrusi titik-titik terbuka pada blok-blok atau bongkahan batuan andesit yang ada di teras Kali Areng.

Kaitannya dengan industri litik pendukung gua-gua hunian Sampung khususnya Ceruk Layah ada dua faktor yang sangat mempengaruhi pola pikir mereka dalam mengeksploitasi bahan baku sebagai bahan utama dalam membuat artefak litik. Pertama adalah faktor ekonomis. Faktor ini cukup menentukan karena mereka tidak 
cukup banyak membuang waktu dan tenaga serta jarak jangkau mereka untuk memperoleh bahan baku baik dalam bentuk blok/bongkahan berukuran relatif kecil atau sedang. Mereka memangkas pada blok/bongkahan yang ada, atau membawanya ke lokasi hunian untuk kemudian diserpih menjadi bentuk-bentuk artefak. Efisiensi ini membawa mereka pada suatu pola kerja yang cenderung hanya tergantung pada sumberdaya alam sekitarnya dan juga terhadap proses kehidupan yang praktis. Kedua adalah faktor oportunis, yaitu tidak adanya usaha untuk mendapatkan hasil yang diinginkan dalam membuat suatu bentuk peralatan kerja atau yang khas bagi mereka, tetapi hanya ingin mendapatkan sebanyak mungkin serpih dan serpihan litik yang selanjutnya digunakan seperlunya, sedang selebihnya dibiarkan begitu saja atau akan dipergunakan pada waktu yang tidak ditentukan yang disesuaikan dengan kondisi alam saat itu. Kedua faktor ini tentu juga menghasilkan hal-hal yang menguntungkan ataupun merugikan. Keuntungan dari proses faktor pertama adalah mereka tidak perlu membuang waktu meninggalkan aktivitas sehari-hari serta hanya memerlukan jarak yang tidak cukup jauh untuk mendapatkan bahan baku artefak litik, sedang ruginya cenderung pada ketergantungan terhadap bahan baku yang notabene tidak mempunyai kualitas baik menjadikan artefak-artefak tersebut ke bentuk dan tipe peralatan yang tidak berkembang. Keuntungan dari proses faktor kedua adalah mereka cukup banyak mempunyai persediaan bahan atau artefak (serpih dan serpihan) dalam membuat alat, karena cukup banyak yang telah mereka hasilkan dalam tahapan pemangkasan dan penyerpihan sebelumnya. Untuk ruginya adalah tidak adanya kualitas batuan yang baik dan umumnya berupa artefak-artefak kecil (microlit) dan tidak beraturan yang dominan oleh artefak kortikal (cortical flakes). Hasil pengamatan geologis yang dipadukan dengan faktor-faktor tersebut di atas menunjukkan bahwa eksploitasi bahan baku terhadap keberadaan industri litik masa plestosen-holosen di wilayah ini memang lebih mengandalkan pada bahan baku yang ada di sekitarnya.

\section{Pengaruh Bahan Baku dengan Kualitas Produk Alat.}

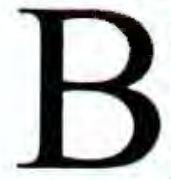
ahan baku dalam hal ini batuan, sangat menentukan kualitas produk industri litik. Karenanya dalam pemilihan bahan untuk pembuatan alat, hal-hal yang perlu dipertimbangkan antara lain meliputi (Greisser and Payson D. Sheets, 1979): (a) kekerasan (istilah kekerasan ada dua yaitu hardness dan taughness. Hardness yaitu daya tahan untuk mengalami perubahan bentuk secara permanen, sedangkan toughness merupakan daya tahan untuk mengalami keretakan); (b) kerapuhan; (c) kekenyalan atau elastisitas (resiliency) yaitu kemampuan untuk kembali ke bentuk semula setelah ditekan atau direnggangkan); dan (d) kemudahan untuk diserpih (sifat ini berhubungan dengan homogenitas bahan, sehingga memungkinkan pembuat alat untuk memukul bahan dari segala arah). Bahan batuan yang dianggap memenuhi keempat hal tersebut adalah batuan yang bertekstur crypotocrystalline (memiliki butiran kristal penyusunnya sangat halus $\pm 0.01 \mathrm{~mm}$ ), 
isotropic (batuan yang mempunyai sifat sama di seluruh bagian batuan), dan mengandung kadar silika tinggi.

Pemilihan bahan dengan kandungan silika tinggi disebabkan pada sifat silika. Silika $\left(\mathrm{SiO}_{2}\right)$ merupakan senyawa antara silikon dan oksigen. Silika terdapat di mana-mana dalam mineral silikat yang membentuk batuan dan merupakan bagian utama kerak bumi. Dalam silikat, silika bersenyawa atau bercampur dengan aneka senyawa lain. Dalam kuarsa dan beberapa mineral lain, silika berada sendirian. Silika mempunyai bentuk kristalin (koesit, kristabolit, kuarsa, dan stishovit) dan amorf (lechatlierit, opal, dan lain-lain). Kuarsa merupakan bentuk paling umum dari silika kristalin.

Beberapa bahan yang sering digunakan untuk pembuatan alat yang mengandung silika atau biasa disebut kersikan baik dalam kadar tinggi maupun rendah seperti bahanbahan berikut. Kuarsa merupakan batuan beku yang kaya akan silika dan alumina, jernih, tak berwarna, kadang-kadang berwarna putih susu atau kelabu. Obsidian merupakan batuan beku luar (extrusive igneous rock) gelas volkanik masif yang mempunyai pecahan conchoidal, berwarna cerah dan berkilap gelas, jika banyak mengandung magnetite dan masic mineral lain akan berwarna hitam. Kadang-kadang berwarna kuning, merah, atau coklat karena magnetite dan hematite. Gamping kersikan termasuk batuan sedimen non klastik yang mineral penyusunnya berupa kalsit, dan bertekstur medium grained (1/16-2 mm) sampai coarse grained (lebih dari $2 \mathrm{~mm}$ ). Selain itu jenis kalsedon lainnya adalah jasper, tidak tembus cahaya, dan warnanya bervariasi.

Chert atau batu api merupakan kuarsa $\left(\mathrm{SiO}_{2}\right)$ dalam bentuk butiran halus. Kuarsa ini dikenal sebagai batu api, karena bila diadu dengan baja atau batu lain akan memercikkan bunga api yang dapat membakar selulosa kering. Dalam klasifikasi batuan termasuk batuan sedimen non klastik yang tersusun atas mineral kalsedon, dan tidak tembus cahaya. Umumnya bagian dalam berwarna lebih gelap daripada lapisan luar. Chert atau rijang (istilah lokal) mudah dipangkas dan dibentuk, dengan serpihan yang cenderung mempunyai sisi yang tajam. Jenis batuan ini sangat umum digunakan dalam industri alat batu prasejarah.

Basal( $\mathrm{t}$ ) merupakan batuan beku berwarna gelap, berbutir halus yang umumnya dari pembekuan lava gunungapi, terutama gunungapi di tengah samudera. Mineral pembentukannya adalah plagioklas dan piroksen serta sedikit olivin. Basal sangat sulit dikerjakan untuk menghasilkan alat yang baik. Sifatnya yang kasar membuat serpihbilah yang dihasilkan sangat jarang memiliki sisi yang tajam. Kekasarannya pula yang membuat sulit untuk menciptakan berbagai bentuk dan tajaman seperti yang diinginkan si pembuat. 
Sebagaimana telah disinggung pada bab B, produk alat batu dengan silikaan rendah akan menghasilkan alat-alat berukuran besar, sedangkan bahan baku dengan silikaan tinggi mampu menghasilkan produk alat berukuran kecil dengan teknik pemangkasan sekunder (retus) berukuran mikro. Dalam konteks tersebut dapat diamati secara jelas perbedaan produk alat antara Gua Macan (batugamping) dengan Ceruk Layah (rijang/chert dan kalsedon). Berikut produk alat litik dari kedua gua tersebut dengan bahan baku batu yang berbeda.

\section{Droduk Alat Litik Gua Macan}

Industri litik dari Gua Macan menunjukkan produk alat berukuran besar (seperti : serpih besar, bilah, serut, kapak perimbas, kapak penetak, dan pelandas). Kualitas industri litik dapat diuraikan sebagai berikut (Nurani, 2002a).

Temuan industri litik Gua Macan secara garis besar dapat diuraikan sebagai berikut :

- Tipe clacton sangat jelas eksistensinya. Pemangkasan hanya dilakukan pada bagian dorsalnya saja.

- Jumlah pangkasan bervariasi, dari pemangkasan tunggal memanjang hingga pemangkasan yang lebih kompleks. Pemangkasan dilakukan secara terjal dan mendekati vertikal.

- Intensitas pemangkasan juga beragam, dari yang belum dipakai, pemakaian cukup intensif, dan pemakaian sangat intensif.
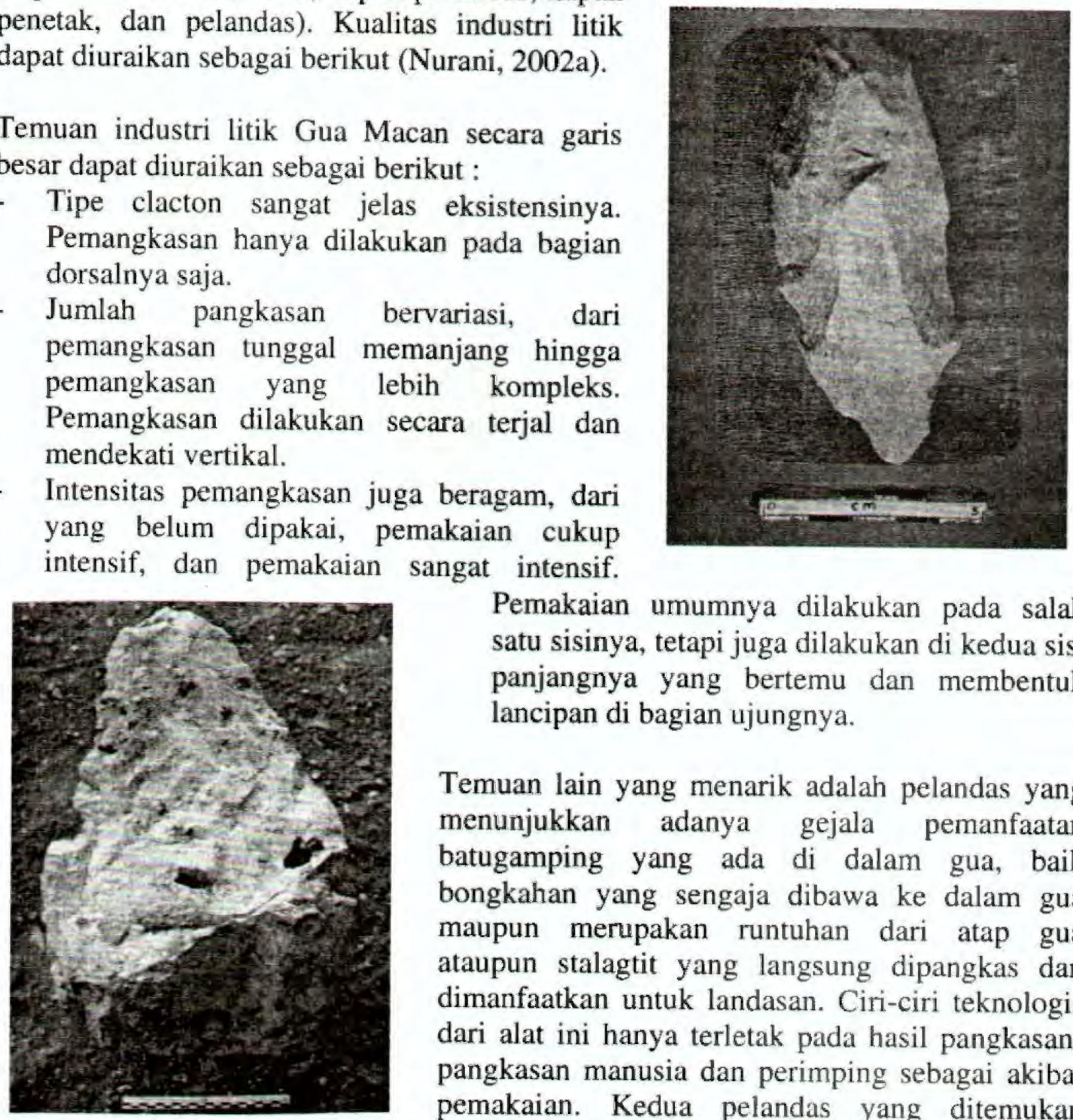

Pemakaian umumnya dilakukan pada salah satu sisinya, tetapi juga dilakukan di kedua sisi panjangnya yang bertemu dan membentuk lancipan di bagian ujungnya.

Temuan lain yang menarik adalah pelandas yang menunjukkan adanya gejala pemanfaatan batugamping yang ada di dalam gua, baik bongkahan yang sengaja dibawa ke dalam gua maupun merupakan runtuhan dari atap gua ataupun stalagtit yang langsung dipangkas dan dimanfaatkan untuk landasan. Ciri-ciri teknologis dari alat ini hanya terletak pada hasil pangkasanpangkasan manusia dan perimping sebagai akibat pemakaian. Kedua pelandas yang ditemukan 
merupakan runtuhan dari atap gua dengan ukuran besar, sehingga tidak dapat diangkat.

Berbeda halnya dengan teknologi yang diterapkan pada serpih-bilah yang sebagian besar hanya memiliki ciri-ciri adanya pengerjaan manusia, sedangkan ciri-ciri yang ditimbulkan oleh sifat dan jenis batuannya hampir tidak ada. Hal ini disebabkan oleh rendahnya kualitas bahan. Ciri-ciri buatan manusia itulah yang kemudian secara tegas membedakan kategori alat serpih ini dengan tatal batu maupun pecahan batu.

Dengan adanya ciri-ciri tertentu tersebut, dapat dipastikan bahwa pelepasan alat-alat non-masif ini dari batu intinya dilakukan dengan pukulan tidak langsung (indirectpercussion). Faset-faset (bulbus negatif) pada bagian dorsal dibentuk terlebih dahulu, kemudian diikuti dengan pembuatan dataran pukul, dan dengan menggunakan perkutor, alat-alat serpih ini dilepaskan dari batu intinya. Bagian ventral dibiarkan polos, tanpa dihaluskan melalui pemangkasan kedua. Cara pembuatan seperti ini akan dapat dilakukan hingga pembuatan alat serpih paling kecil, seperti halnya yang ditunjukkan oleh spesimen dari kotak F-5. Spesimen yang berukuran $1.7 \mathrm{x}$

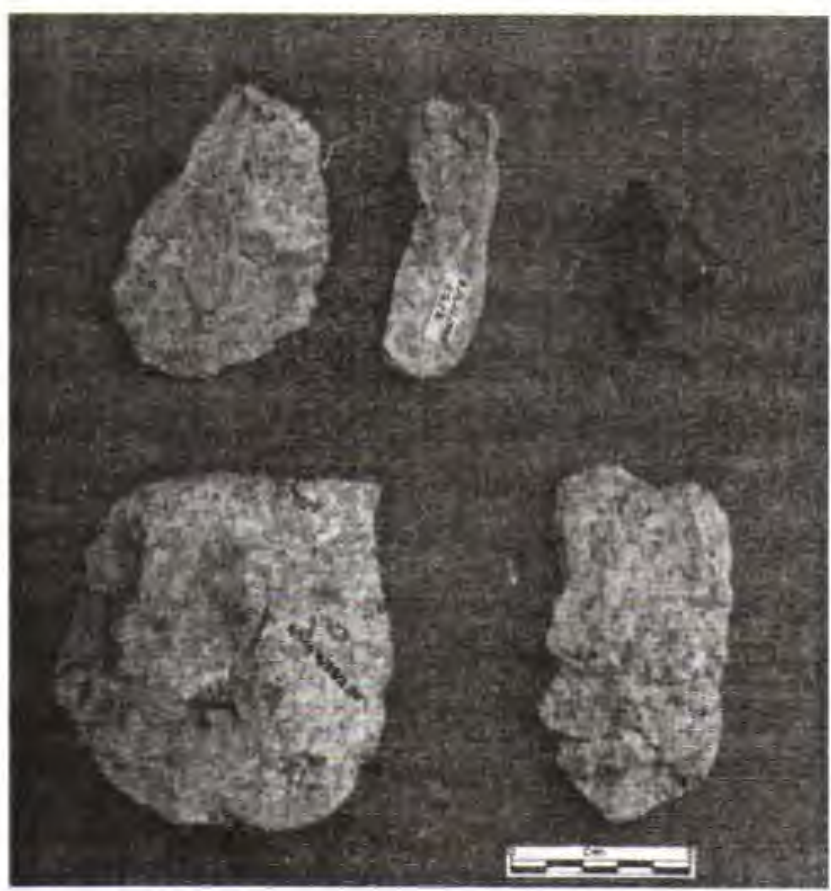
$1.8 \times 0.3 \mathrm{~cm}$ itu dibuat dari kalsedon kuning tembus, yang termasuk jenis bahan berkualitas tinggi. Oleh karena itu, selain ciri-ciri penanganan manusia (bagian dorsal berfaset, bagian ventral polos, eksistensi dataran pukul), juga dapat diamati adanya alur penyerpihan (ripples) di bagian ventral. Dari seluruh himpunan alat serpih ini, spesimen di atas merupakan satu-satunya spesimen yang menunjukkan adanya ripples di bagian ventral.

\section{Droduk Alat Litik Ceruk Layah}

1 Temuan alat litik dari Ceruk Layah meliputi alat serpih dengan atau tanpa retus pemakaian, bilah, dan serut. Serpih tanpa retus pada umumnya memiliki ciri-ciri teknologis yang lengkap sebagai hasil pengerjaan manusia, yaitu hadirnya dataran pukul, bulbus, dan terkadang luka pukul. Bentuknya bervariasi sebagaimana juga ukurannya. Sedangkan serpih dengan retus memiliki ciri-ciri teknologis, morfologis, dan metrik yang sama dengan serpih tanpa retus. Perbedaannya hanya terletak pada kehadiran retus di bagian tertentu dari sisinya, retus-retus tersebut merupakan bekasbekas pengerjaan penyem-purnaan agar sisi tersebut lebih "efficace" dalam pemakaiannya. Selain itu serpih dengan retus cenderung dibentuk segitiga secara 
sengaja selanjutnya dibuat retus baik secara bergerigi maupun dalam ukuran mikro atau cekung pada bagian lateral.

Temuan alat serpih dari hasil ekskavasi sebagian besar merupakan serpih yang dipersiapkan yaitu dengan membuat pangkasan-pangkasan pada bagian dorsal dan selanjutnya dilepaskan dari batu inti secara tidak langsung dengan menggunakan perkutor secara keras. Pangkasan pada bagian dorsal antara 3--6 yang dilakukan secara longitudinal dan beberapa dilakukan secara sentripetal. Hal yang menjadi kekhasan alat serpih pada Ceruk Layah ini adalah berpunggung tinggi dan tebal (Nurani, 2002b).

Beberapa alat serpih yang sengaja dibentuk segitiga dengan pembuatan retus secara efektif pada bagian lateral terutama tampak pada temuan kotak C-5 pada kedalaman antara 28 s.d. $45 \mathrm{~cm}$ dari permukaan tanah sejumlah 11 buah. Serpih dipersiapkan dengan bagian dorsal dipangkas secara longitudinal menyudut (berpunggung tinggi). Bagian ventral dibiarkan polos. Setelah lepas dari batu inti dibuat retus gigir secara intensif pada bagian lateral baik kanan maupun kiri. Peretusan tampak adanya kesengajaan dibuat struktur segitiga meruncing. Ukuran serpih ini adalah 4,2 x 3,2 1 $\mathrm{cm}$.

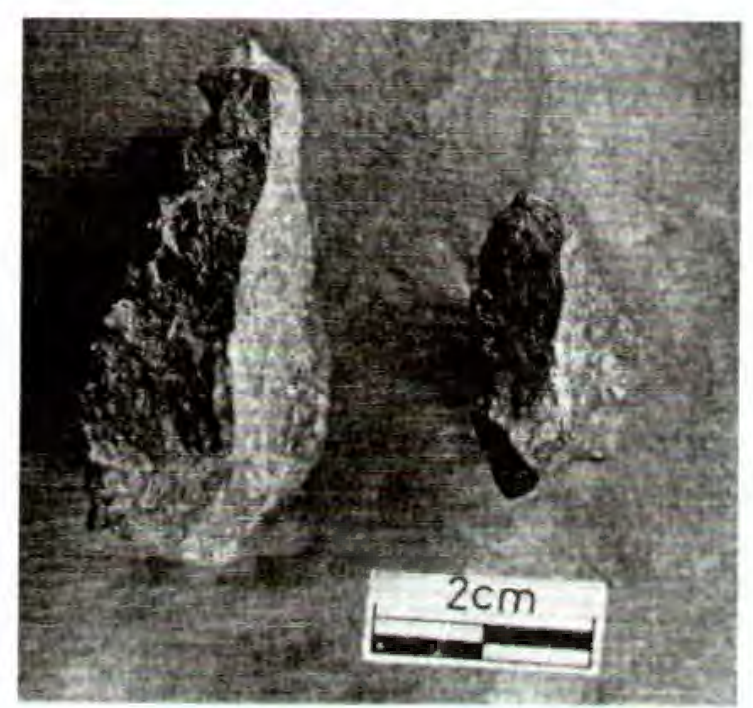

puncak dorsal berpunggung tinggi.

Bentuk segitiga pada sebagian besar alat serpih ini tampaknya cenderung akan dibuat matapanah, namun belum sempurna. Beberapa spesimen masih tampak adanya dataran pukul yang tebal, namun dari segi pembuatan retus tampak intensif dengan membentuk retus mikro dan bergigir
Kemungkinan serpih ini merupakan mata panah berdasar cembung. Temuan serupa yang ditemukan pada kedalaman yang sama adalah berupa serpih yang dipersiapkan dengan membuat pangkasan-pangkasan pada bagian dorsal, pangkasan longitudinal yang diikuti dengan pangkasan secara transversal, sehingga tampak seperti bentuk daun. Terdapat jejakjejak pemakaian secara intensif pada bagian lateral kanan. Bagian lateral menipis sementara

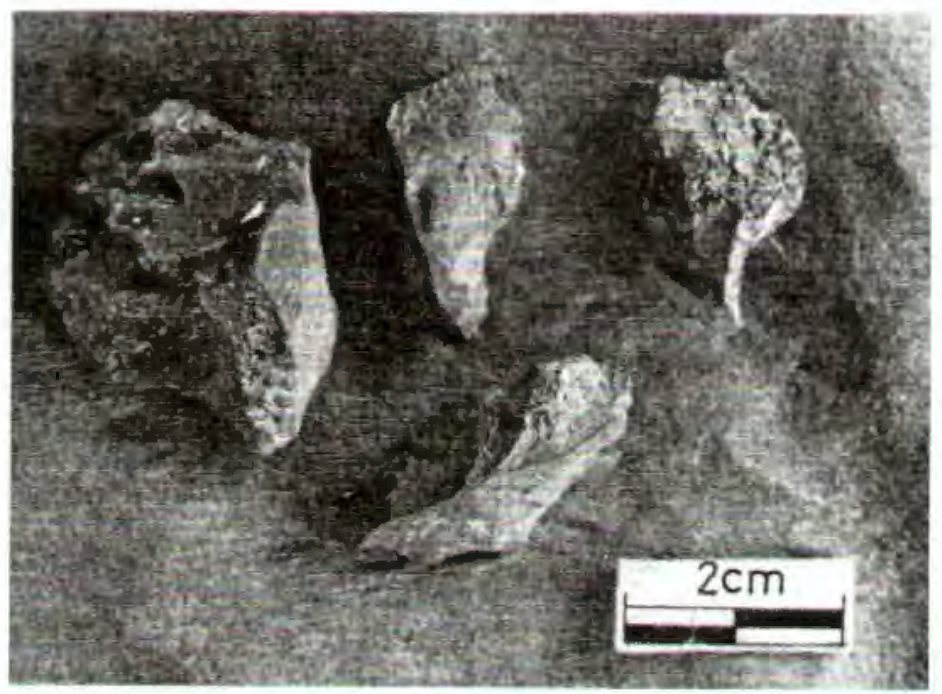


pada bagian lateral baik kiri maupun lateral kanan. Selain itu bekas-bekas pemakaian (perimping) juga menunjukkan tingkat intensif yang tinggi.

Temuan alat serpih selain berbentuk segitiga sebagaimana telah diuraikan di atas, terdapat pula tipe yang menarik yaitu tipe bor. Bor merupakan alat dimana pada bagian tertentu (umumnya di bagian distal) terdapat bagian meruncing yang dibentuk secara sengaja. Pada umumnya bentuk dasar runcingan telah tercipta pada serpih, melalui persiapan-persiapan awal sebelum pemisahan dari batu inti. Bentuk dasar ini kemudian disempurnakan melalui peretusan sisi atau pembuatan cekungan pada kedua sisi runcingan. Letak runcingan dapat melahirkan beberapa bentuk bor, adakalanya terletak pada salah satu sudut dengan arah runcingan menyilang terhadap sumbu morfologi alat.

Selain itu letak runcingan ada juga di bagian tengah sisi distal bertumpu pada sumbusumbu morfologi alat. Sering pula runcingan dibuat dengan mengerjakan salah satu sisi lebih intensif dari sisi lain sehingga melahirkan bentuk khas melengkung. Bor ditemukan pada kotak C-5 kedalaman 28 - $45 \mathrm{~cm}$ dari permukaan tanah, yang dicirikan oleh runcingan yang berbentuk miring melengkung menyerupai paruh burung. Dalam pembentukan runcingan tampak adanya kesengajaan. Sedangkan pada bagian lateral kiri dan kanan terdapat retus yang dibuat secara mikro dan cekungan kecil. Berdasarkan pengamatan, tampaknya alat ini dilakukan secara intensif baik pada bagian distal, proksimal, maupun lateral. Ukuran bor ini adalah $3,1 \times 1,5 \times 0,7 \mathrm{~cm}$. Temuan lain adalah dari kotak C-4 kedalaman $10-40 \mathrm{~cm}$ yaitu pada bagian dorsal dipangkas secara longitudinal, selanjutnya setelah terlepas dari batu inti dibuat tajaman melengkung secara sengaja, sementara bagian distal dibuat retus mikro secara bergigir. Spesimen ini menunjukkan hanya pada salah satu lateral saja yang dibuat retus bergigir secara intensif. Ukuran bor ini adalah $2,5 \times 1,3 \times 0,6 \mathrm{~cm}$.

Bilah (blade) secara teknologis sama dengan serpih, perbedaan yang mendasar antara alat serpih dengan bilah adalah pada bentuk alat atau dari aspek morfologisnya saja. Alat serpih berbentuk pipih melebar, sedangkan bilah berbentuk memanjang dengan

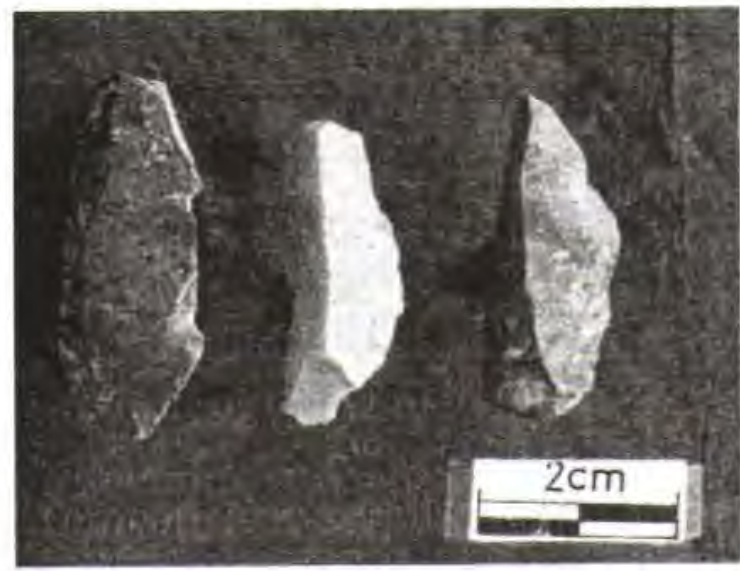
ukuran panjang minimal 2 kali ukuran lebarnya. Kedua sisi panjang umumnya bertemu di ujung dan membentuk lancipan. Bagian ventral dibiarkan polos tanpa faset namun ada juga yang dipangkas lagi dengan satu pangkasan memanjang untuk penipisan. Sedangkan bagian dorsal biasanya dipangkas melalui faset-faset penyerpihan yang sudah dipersiapkan. Pada bagian dorsal umumnya didominasi oleh pangkasan memanjang yang membentuk punggung alat dengan penampang 
Temuan bilah ditemukan pada kotak C-4 kedalaman $10-40 \mathrm{~cm}$ sejumlah 3 buah. Hal yang tampak jelas adalah adanya kesengajaan serpih yang dibuat secara memanjang, 3 pangkasan secara longitudinal dibentuk pada bagian dorsal, sementara bagian ventral dibiarkan polos. Pada bagian lateral dibuat retus mikro. Ukuran bilah ini adalah 3,7 $\mathrm{x}$ $1,6 \times 0,8 \mathrm{~cm}$.

Serut (scraper) adalah alat yang telah dipakai, yang tidak menunjukkan ciri teknologis seperti yang ditunjukkan oleh alat serpih dan bilah. Unsur pemakaian dan ukuran alat yang tergolong alat nonmasif merupakan kriteria terpenting untuk kategori alat ini. Tidak ada pembentukan melalui pemangkasan ataupun penyerpihan untuk memperoleh bagian tajamannya. Oleh karena itu, serut dapat berupa serpihan-serpihan batu ataupun sekedar batu alam yang kemudian dipakai. Tidak adanya kriteria yang mendasar untuk masalah teknologis ini menyebabkan kemungkinan bergantinya kategori serut apabila dihadapkan pada ukuran alat besar (alat masif) yang dikategorikan sebagai kapak perimbas. Berdasarkan pada kriteria unsur pemakaian inilah, maka dalam tipe alat serut muncul tipe-tipe lain yang ditunjukkan pada keletakan retus atau unsur pemakaian. Adapun tipe-tipe serut meliputi serut ujung, samping, bergigir, cekung, cembung, dan sebagainya.

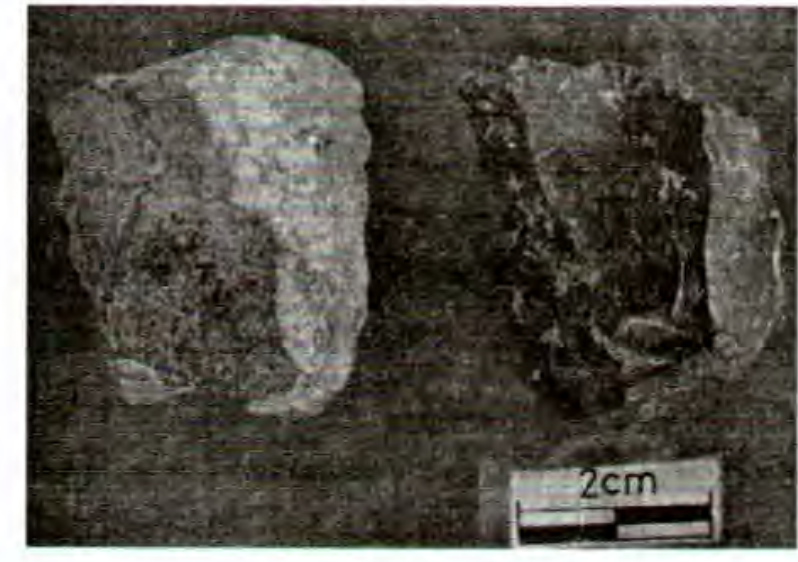
pada kedalaman antara $10-40$ pada kotak C-4 ini juga ditemukan sebuah serut cekung. Cekungan tampak sengaja dibuat selanjutnya dibuat retus cekungan, pada bagian lateral dibuat retus mikro. Ukuran serut ini adalah $2,5 \times 1,7 \times 0,7 \mathrm{~cm}$ dari bahan rijang hijau.

Tipe ini ditemukan pada kotak C-4 kedalaman $40-81 \mathrm{~cm}$ dari permukaan tanah.
Untuk pembuatan cekungan pada serut ini
melalui satu pangkasan, selanjutnya dibentuk
retus mikro. Selain itu pada bagian ujung
(distal) dibuat retus secara intensif.
Kemungkinan selain difungsikan sebagai
serut juga digunakan sebagai bor melibat
runcingnya bagian distal yang dilanjutkan
pembuatan retus sekelilingnya. Selain itu
kotak C-4 ini juga ditemukan sebuab serut
buat selanjutnya dibuat retus cekungan, pada
ran serut ini adalah $2,5 \times 1,7 \times 0,7 \mathrm{~cm}$ dari Untuk pembuatan cekungan pada serut ini
melalui satu pangkasan, selanjutnya dibentuk
retus mikro. Selain itu pada bagian ujung
(distal) dibuat retus secara intensif.
Kemungkinan selain difungsikan sebagai
serut juga digunakan sebagai bor melibat
runcingnya bagian distal yang dilanjutkan
pembuatan retus sekelilingnya. Selain itu
kotak C-4 ini juga ditemukan sebuab serut
buat selanjutnya dibuat retus cekungan, pada
ran serut ini adalah $2,5 \times 1,7 \times 0,7 \mathrm{~cm}$ dari Untuk pembuatan cekungan pada serut ini
melalui satu pangkasan, selanjutnya dibentuk
retus mikro. Selain itu pada bagian ujung
(distal) dibuat retus secara intensif.
Kemungkinan selain difungsikan sebagai
serut juga digunakan sebagai bor melibat
runcingnya bagian distal yang dilanjutkan
pembuatan retus sekelilingnya. Selain itu
kotak C-4 ini juga ditemukan sebuab serut
buat selanjutnya dibuat retus cekungan, pada
ran serut ini adalah $2,5 \times 1,7 \times 0,7 \mathrm{~cm}$ dari Untuk pembuatan cekungan pada serut ini
melalui satu pangkasan, selanjutnya dibentuk
retus mikro. Selain itu pada bagian ujung
(distal) dibuat retus secara intensif.
Kemungkinan selain difungsikan sebagai
serut juga digunakan sebagai bor melibat
runcingnya bagian distal yang dilanjutkan
pembuatan retus sekelilingnya. Selain itu
kotak C-4 ini juga ditemukan sebuab serut
buat selanjutnya dibuat retus cekungan, pada
ran serut ini adalah $2,5 \times 1,7 \times 0,7 \mathrm{~cm}$ dari Untuk pembuatan cekungan pada serut ini
melalui satu pangkasan, selanjutnya dibentuk
retus mikro. Selain itu pada bagian ujung
(distal) dibuat retus secara intensif.
Kemungkinan selain difungsikan sebagai
serut juga digunakan sebagai bor melibat
runcingnya bagian distal yang dilanjutkan
pembuatan retus sekelilingnya. Selain itu
kotak C-4 ini juga ditemukan sebuab serut
buat selanjutnya dibuat retus cekungan, pada
ran serut ini adalah $2,5 \times 1,7 \times 0,7 \mathrm{~cm}$ dari Untuk pembuatan cekungan pada serut ini
melalui satu pangkasan, selanjutnya dibentuk
retus mikro. Selain itu pada bagian ujung
(distal) dibuat retus secara intensif.
Kemungkinan selain difungsikan sebagai
serut juga digunakan sebagai bor melibat
runcingnya bagian distal yang dilanjutkan
pembuatan retus sekelilingnya. Selain itu
kotak C-4 ini juga ditemukan sebuab serut
buat selanjutnya dibuat retus cekungan, pada
ran serut ini adalah $2,5 \times 1,7 \times 0,7 \mathrm{~cm}$ dari Untuk pembuatan cekungan pada serut ini
melalui satu pangkasan, selanjutnya dibentuk
retus mikro. Selain itu pada bagian ujung
(distal) dibuat retus secara intensif.
Kemungkinan selain difungsikan sebagai
serut juga digunakan sebagai bor melibat
runcingnya bagian distal yang dilanjutkan
pembuatan retus sekelilingnya. Selain itu
kotak C-4 ini juga ditemukan sebuab serut
buat selanjutnya dibuat retus cekungan, pada
ran serut ini adalah $2,5 \times 1,7 \times 0,7 \mathrm{~cm}$ dari Untuk pembuatan cekungan pada serut ini
melalui satu pangkasan, selanjutnya dibentuk
retus mikro. Selain itu pada bagian ujung
(distal) dibuat retus secara intensif.
Kemungkinan selain difungsikan sebagai
serut juga digunakan sebagai bor melibat
runcingnya bagian distal yang dilanjutkan
pembuatan retus sekelilingnya. Selain itu
kotak C-4 ini juga ditemukan sebuab serut
buat selanjutnya dibuat retus cekungan, pada
ran serut ini adalah $2,5 \times 1,7 \times 0,7 \mathrm{~cm}$ dari Untuk pembuatan cekungan pada serut ini
melalui satu pangkasan, selanjutnya dibentuk
retus mikro. Selain itu pada bagian ujung
(distal) dibuat retus secara intensif.
Kemungkinan selain difungsikan sebagai
serut juga digunakan sebagai bor melibat
runcingnya bagian distal yang dilanjutkan
pembuatan retus sekelilingnya. Selain itu
kotak C-4 ini juga ditemukan sebuab serut
buat selanjutnya dibuat retus cekungan, pada
ran serut ini adalah $2,5 \times 1,7 \times 0,7 \mathrm{~cm}$ dari irisan transversal berbentuk segitiga.

Berkala Arkeologi Th. XXIV (1) 


\section{Kesimpulan}

D erdasarkan uraian di atas dapat disimpulkan hal-hal penting sebagai berikut:

* Penghuni gua-gua di Jawa Timur dalam mengembangkan industri litik sangat dipengaruhi lingkungan alam sekitarnya untuk menerapkan teknologi yang dikenalnya.

* Bahan baku dalam hal ini jenis batuan mempengaruhi produk alat. Sementara itu teknologi litik yang dikenalnya tampak jelas pada produk industri litik meskipun dari bahan baku dengan tingkat silikaan rendah.

* Kasus produk alat litik pada kedua kelompok gua yaitu di Gunung Watangan, Jember dengan di Sampung, Ponorogo menunjukkan tingkat teknologi litik yang dikenal sederajat, namun bahan baku batuan berbeda tingkat silikaannya. Pada industri litik di Gunung Watangan menunjukkan produk alat berukuran relatif besar (masif) sementara di Sampung menghasilkan produk alat kecil (mikrolit). Kenyataan tersebut menunjukkan penerapan teknologis litik akan tampak jelas meskipun dengan bahan baku yang berbeda.

* Pengaruh bahan baku batuan tampak pada ukuran alat. Pada kelompok gua di Gunung Watangan yang menggunakan batuan dengan tingkat silikaan rendah (batugamping) dituntut artisan yang andal. Hal tersebut disebabkan jenis batuan mudah rapuh dan pengendalian pangkasan sulit. Produk alat pada kelompok ini menunjukkan ukuran relatif besar (masif) disebabkan pangkasan dan penyerpihan yang diterapkan tidak optimal. Sedangkan produk alat pada kelompok gua di Sampung, Ponorogo merupakan alat mikrolit. Hal itu disebabkan bahan baku batuan memiliki tingkat silikaan relatif tinggi (rijang/chert dan kalsedon). Teknologi litik yang dikenalnya dapat dilakukan secara optimal sehingga menghasilkan produk alat berukuran kecil dengan pangkasan dan penyerpihan mikro baik primer maupun sekunder. 


\section{KEPUSTAKAAN}

Crabtree, Don E. 1972, An Introduction to Flintworking. Idaho : Occasional Papers of The Museum Idaho State University.

Greisser, Sally T. and Payson D. Sheets, 1979. Raw Materials as a Functional Variable in Use-Wear Studies. In Brian Hayden (ed.), Lithic Use-Wear Analysis. New York : Academic Press. pp. 289--296

Hodges, Henry, 1964. Artifacts An Introduction to Early Materials and Technology. London : John Baker Publishers Ltd.

Nurani, Indah Asikin, 2002a. Berita Penelitian Arkeologi : Pola Pemanfaatan Lahan Gua Pada Komunitas Gunung Watangan. Yogyakarta : Balai Arkeologi.

--.---.-----, 2002b. Laporan Penelitian Arkeologi : Pola Pemanfaatan Lahan Gua-gua di Kabupaten Ponorogo. Belum terbit

Simanjuntak, H. T. (1999). Budaya Awal Holosen Di Gunung Sewu. Berkala Arkeologi, 19(1), 1-20. https://doi.org/10.30883/jha.v19i1.789

Soejono, R.P., 1981. Tinjauan tentang Pengkerangkaa Prasejarah Indonesi Aspekaspek Arkeologi Indonesia. Jakarta : Pusat Penelitian Arkeologi Nasional

Widianto, Harry, 1984. Temuan Alat Paleolitik dari Situs Mulyorejo, Cepu. Artefak hlm. 30--39. Buletin Himpunan Mahasiswa Arkeologi Fakultas Sastra Universitas Gadjah Mada. 